\title{
Esterification vs. 1,3-Dipolar Cycloaddition Synthetic Approaches for Preparation of the Fluorescently Labelled Iron(II) Clathrochelates ${ }^{\dagger}$
}

\author{
Roman A. Selin, ${ }^{\mathrm{a} @ 1}$ Viktor Ya. Chernii, ${ }^{\mathrm{a}}$ Dmytro V. Kryvorotenko, ${ }^{\mathrm{b}}$ Andriy Mokhir, ${ }^{\mathrm{c}}$ \\ and Yan Z. Voloshind,e@2 \\ ${ }^{a}$ V.I. Vernadskii Institute of General and Inorganic Chemistry NASU, 03080 Kyiv, Ukraine \\ 'Institute of Molecular Biology and Genetics, NASU, 03680 Kyiv, Ukraine \\ 'Organic Chemistry II, Friedrich-Alexander-University of Erlangen-Nuremberg, 91054 Erlangen, Germany \\ ${ }^{\mathrm{d}}$ N.S. Kurnakov Institute of General and Inorganic Chemistry of the Russian Academy of Sciences, 119991 Moscow, Russia \\ ${ }^{\mathrm{e}}$ A.N. Nesmeyanov Institute of the Organoelement Compounds of the Russian Academy of Sciences, 119991 Moscow, Russia \\ ${ }^{\circledR 1}$ Corresponding author E-mail: selin.roman.oleksandrovich@gmail.com \\ ${ }^{\circledR 2}$ Corresponding authorE-mail: voloshin@ineos.ac.ru
}

\begin{abstract}
Two most common synthetic approaches (i.e. the esterification and 1,3-dipolar cycloaddition reactions) to a functionalization of the reactive three-dimensional molecular platforms, allowing to obtain the fluorescently labelled iron(II) clathrochelates and, therefore, to study their localization and accumulation in cancer cells, were compared. Because an esterification approach gave the target complexes in a very low yield, if any, such a functionalization of a known propargylamine iron(II) clathrochelate complex with terminal $C \equiv C$ bond as a reactive macrobicyclic precursor by the copper-promoted 1,3-dipolar cycloaddition "click" reaction was also tested. This one-pot synthetic procedure allowed to obtain the cumarin-terminated iron(II) cage complex in a high yield; it was characterized using elemental analysis, ESI-TOF mass, and ${ }^{1} H$ and ${ }^{13} C\left\{{ }^{1} H\right\}$ NMR spectra.
\end{abstract}

Keywords: Macrocyclic compounds, clathrochelates, iron complexes, ligand reactivity, nucleophilic substitution, esterification, 1,3-dipolar cycloaddition, molecular probes, fluorescent reporters.

\section{Сравнение реакций этерификации и 1,3-Аиполярного циклоприсоединения как синтетических поАходов к получению флуоресцентно-меченых клатрохелатов железа(II)}

\author{
Р. А. Селин, ${ }^{\text {@ } 11}$ В. Я. Черний, ${ }^{\mathrm{a}}$ А. В. Криворотенко, ${ }^{\mathrm{b}}$ А. Мохир, ${ }^{\mathrm{c}}$ \\ Я. 3. Волошин ${ }^{\mathrm{d}, \mathrm{e} 2}$
}

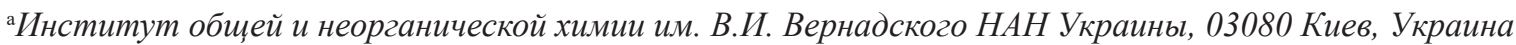

${ }^{\mathrm{b}}$ Институт молекулярной биологии и генетики НАН Украины, 03680 Киев, Украина

${ }^{\mathrm{c}}$ Институт органической химии II, Университет Эрлангена-Нюрнберга, 91054 Эрланген, Германия

${ }^{\mathrm{d}}$ Институт общей и неорганической химии им. Н.С. Курнакова РАН, 119991 Москва, Россия

${ }^{\mathrm{e}}$ Институт элементоорганических соединений им. А.Н. Несмеянова РАН, 119991 Москва, Россия

${ }^{\circledR 1}$ E-mail: selin.roman.oleksandrovich@gmail.com

${ }^{\circledR 2}$ E-mail:voloshin@ineos.ac.ru
\end{abstract}

В работе приводится сравнение двух наиболее распространенных синтетических подходов (реакции этерификации и 1,3-диполярного циклоприсоединения) к функционализации реакционноспособных трехмерных молекулярных платформ, позволяющих получать флуоресцентно-меченые клатрохелаты железа(II) и, таким

\footnotetext{
${ }^{\dagger}$ The authors dedicate this paper to the memory of Prof. Oleg Varzatskii and Prof. Vladislava Kovalska who have suddenly passed away on December 2017 and on December 2020.
} 
образом, установить их локализацию и накопление в опухолевых клетках. Поскольку реакция этерификации дала целевые комплексы с очень низкими выходами, была изучена такая функиионализация с использованием медь-катализируемой «клик»-реакиии 1,3-диполярного ииклоприсоединения к известному пропаргиламинсодержамему клатрохелату железа(II) с терминальной $C$ 三-связью как реакиионноспособному макробициклическому предшественнику. Этот одностадийный синтетический подход позволил с высоким выходом получить клеточный комплекс железа(II) с терминальным кумариновым фрагментом, охарактеризованный данными элементного анализа, ESI-TOF масс-спектрометрии, ${ }^{1} \mathrm{H} u{ }^{13} \mathrm{C}\left\{{ }^{\prime l} \mathrm{H}\right\}$ ЯMP-спектроскопии.

Ключевые слова: Макроциклические соединения, клатрохелаты, комплексы железа, реакционная способность лигандов, нуклеофильное замещение, этерификация, 1,3-диполярное циклоприсоединение, молекулярные метки, флуоресцентные репортеры.

\section{Introduction}

Keen interest of bioinorganic chemists and biochemists in the design and synthesis of the functionalized iron(II) clathrochelates ${ }^{[1,2]}$ can be explained by a threedimensional geometry of their molecules, which contain up to eight different functionalizating substituents and each of them can be potentially used for evaluation of new biologically active cage compounds. This feature allows to use a quasiaromatic clathrochelate framework as the reactive molecular platform for the synthesis of pharmaceutically active metal complexes and hybrid organic-inorganic systems based on them, which are the prospective prodrugs for fighting of a series of viral, cancer and neurodegenerative diseases. So, an elaboration of new synthetic strategies and approaches allowing to obtain cage complexes of this type seems to be a very important task. Indeed, the designed iron(II) clathrochelates and bis-clathrochelates are reported to inhibit a biosynthesis of nucleic acids in the transcription systems of $\mathrm{T} 7 \mathrm{RNA}^{[3-5]}$ and Taq $\mathrm{DNA}^{[6]}$ polymerases and a formation of fibrils and their aggregates ${ }^{[7,8]}$ as well to give the strong supramolecular assemblies with globular proteins. $^{[9-13]}$ Moreover, an electrophilic iron(II) hexachloroclathrochelate is described ${ }^{[14]}$ to possess a selective and highly cytotoxic effect against the human leukemia cell line. Unfortunately, a true mechanism of such anticancer activity of the designed iron(II) clathrochelates remains under discussion and this calls to study their localization and accumulation in cancer cells. In the present work, we aimed to compare two most common esterification and 1,3-dipolar cycloaddition (so-called "click") reactions which can be used for functionalization of the iron(II) clathrochelates with terminal fluorophoric group(s), thus giving the prospective cage compounds for their molecular imaging ${ }^{[15]}$ and, therefore, allowing to observe both the localization and accumulation of these macrobicyclic bioeffectors in cancer cells and in the active centers of protein macromolecules interacting with them as well.

\section{Experimental}

\section{Materials and Methods}

The reagents used, $\mathrm{FeCl}_{2} \cdot 4 \mathrm{H}_{2} \mathrm{O}, \alpha$-benzildioxime $\left(\mathrm{H}_{2} \mathrm{Bd}\right)$, $\mathrm{BF}_{3} \cdot \mathrm{O}\left(\mathrm{C}_{2} \mathrm{H}_{5}\right)_{2}, \quad \mathrm{CuI}, \quad$ tris $((1-$ benzyl-4-triazolyl)methyl $)$ amine (TBTA), 1,1'-carbonyldiimidazole (CDI), 3-azido-7-(di)chromen2-one, 2-mercaptoethanol, sorbents, organic bases and solvents were obtained commercially (SAF®). Dichloroglyoxime was obtained by a known procedure. ${ }^{[16]}$ The dichloroclathrochelate precursor $\mathrm{FeBd}_{2}\left(\mathrm{Cl}_{2} \mathrm{Gm}\right)(\mathrm{BF})_{2}$ was prepared as described elsewhere. ${ }^{[17]}$

Analytical data (C, H, N contents) were obtained with a Carlo Erba model 1106 microanalyzer. ESI-TOF mass spectra were obtained using a maXis $4 \mathrm{G}$, UHR TOF mass spectrometer (Bruker Daltonik). ${ }^{1} \mathrm{H}$ and ${ }^{13} \mathrm{C}\left\{{ }^{1} \mathrm{H}\right\}$ NMR spectra of the complexes under study were recorded from their solutions in acetone- $d_{6}$ with a Bruker Avance 400 spectrometer. These ${ }^{1} \mathrm{H}$ and ${ }^{13} \mathrm{C}\left\{{ }^{1} \mathrm{H}\right\}$ NMR measurements were done using the residual signals of this solvent.

\section{Synthesis}

$\mathbf{F e B d}_{2}\left(\mathbf{C l G m}\left(\mathrm{SC}_{2} \mathbf{H}_{4} \mathbf{O H}\right)\right)(\mathbf{B F})_{\mathbf{2}}(\mathbf{1})$ : Complex $\mathrm{FeBd}_{2}\left(\mathrm{Cl}_{2} \mathrm{Gm}\right)$ $(\mathrm{BF})_{2}(500 \mathrm{mg}, 0.669 \mathrm{mmol})$ was dissolved in dichloromethane $(50 \mathrm{~mL})$ at $-40{ }^{\circ} \mathrm{C}$ under argon and the solutions of 2-mercaptoethanol $(23 \mu \mathrm{L}, 0.335 \mathrm{mmol})$ in dichloromethane $(20 \mathrm{~mL})$ and triethylamine $(93 \mu \mathrm{L}, 0.669 \mathrm{mmol})$ in dichloromethane $(20 \mathrm{~mL})$ were simultaneously added dropwise to this solution. The reaction mixture was stirred at $-40{ }^{\circ} \mathrm{C}$ for $2 \mathrm{~h}$ and then it was heated to room temperature. The organic phase was separated, washed with $1 \mathrm{M}$ aqueous hydrochloric acid, water and with $\mathrm{NaCl}$ saturated aqueous solution as well. The obtained mixture of products was chromatographically separated by column chromatography on silica gel (eluent: dichloromethane) and the clathrochelate product with $R_{\mathrm{f}}$ $=0.125$ was obtained by evaporation of elute in a form of the finecrystalline red powder. Yield: $110 \mathrm{mg}(21 \%) .{ }^{1} \mathrm{H}$ NMR $(400 \mathrm{MHz}$, acetone- $\left.d_{\sigma}\right) \delta_{\mathrm{H}}$ ppm: $3.36\left(\mathrm{t}, J 1_{H-} l_{H}=5.9 \mathrm{~Hz}, 2 \mathrm{H}\right), 3.71\left(\mathrm{q}, J l_{H-} l_{H}\right.$ $=5.8 \mathrm{~Hz}, 2 \mathrm{H}), 4.02\left(\mathrm{t}, J 1_{H-} l_{H}=5.5 \mathrm{~Hz}, 1 \mathrm{H}\right), 7.14-7.35(\mathrm{~m}, 20 \mathrm{H})$.

$\left.\mathbf{F e B d}_{2}\left(\mathbf{O H C}_{2} \mathbf{H}_{4} \mathbf{S}\right)_{2} \mathbf{G m}\right)(\mathbf{B F})_{2}$ (2): Complex $\mathrm{FeBd}_{2}\left(\mathrm{Cl}_{2} \mathrm{Gm}\right)$ $(\mathrm{BF})_{2}(200 \mathrm{mg}, 0.27 \mathrm{mmol}), 2$-mercaptoethanol $(39.37 \mu \mathrm{L}$, 2.1 eq.) and triethylamine $(93.13 \mu \mathrm{L}, 2.5 \mathrm{eq})$ were dissolved in dry DMSO $(1 \mathrm{~mL})$ under argon and the reaction mixture was stirred for approximately $30 \mathrm{~min}$; the reaction course was controlled by TLC ( $\mathrm{SiO}_{2}$-foil; eluent: dichloromethane - iso-propanol 95:5 (v/v) mixture). Then the reaction mixture was poured into $1 \mathrm{M}$ aqueous hydrochloric acid $(10 \mathrm{~mL})$ under vigorous stirring and thus obtained orange-red precipitate was filtered off, washed with water and extracted with dichloromethane $(5 \mathrm{~mL})$. The extract was washed with water, dried with $\mathrm{Na}_{2} \mathrm{SO}_{4}$ and rotary evaporated to a small volume. Then, this extract was flashchromatographically separated on silica gel (30-mm layer, eluent: dichloromethane-iso-propanol 19: $1(\mathrm{v} / \mathrm{v})$ mixture). The obtained major elute was evaporated to dryness and the solid residue was dried in vacuo at $40{ }^{\circ} \mathrm{C}$. Yield: $222 \mathrm{mg}$ (almost quantitative). ${ }^{1} \mathrm{H}$ NMR (400 MHz, acetone- $d_{\sigma}$ ) $\delta_{\mathrm{H}} \mathrm{ppm}: 73.37\left(\mathrm{t}, J 1_{H_{-}} 1_{H}=5.9 \mathrm{~Hz}\right.$, $4 \mathrm{H}), 3.66\left(\mathrm{q}, J 1_{H_{-}} 1_{H}=5.8 \mathrm{~Hz}, 4 \mathrm{H}\right), 4.03\left(\mathrm{t}, J 1_{H_{-}} 1_{H}=5.7 \mathrm{~Hz}, 2 \mathrm{H}\right)$, $7.17-29(\mathrm{~m}, 20 \mathrm{H})$.

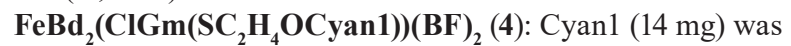
dissolved in dry acetonitrile $(1.5 \mathrm{~mL})$ and $\mathrm{CDI}(6.7 \mathrm{mg}, 1.5 \mathrm{eq}$.) was added. The reaction mixture was stirred for $30 \mathrm{~min}$ and the complex $\mathrm{FeBd}_{2}\left(\mathrm{ClGm}\left(\mathrm{SC}_{2} \mathrm{H}_{4} \mathrm{OH}\right)\right)(\mathrm{BF})_{2}(110 \mathrm{mg}, 5$ eq. $)$ was added. 
The reaction mixture was stirred overnight at room temperature and then water $(1 \mathrm{~mL})$ was added to this mixture. The obtained solution/suspention was stirred for $30 \mathrm{~min}$ and then rotary evaporated to dryness. The obtained solid residue was chromatographically separated on silica gel (eluent: acetonitrile - methanol 3:2 $(\mathrm{v} / \mathrm{v})$ mixture) and the clathrochelate product with $\mathrm{R}_{\mathrm{f}}=0.6$ was isolated in a trace amount as described above.

$\mathbf{F e B d}_{\mathbf{2}}\left(\left(\mathbf{C y a n} \mathbf{1 O C}_{\mathbf{2}} \mathbf{H}_{\mathbf{4}} \mathbf{S}\right)_{\mathbf{2}} \mathbf{G m}\right)(\mathbf{B F})_{\mathbf{2}} \mathbf{( 5 )}$ : Cyan1 (25 mg) was dissolved in dry acetonitrile $(1.5 \mathrm{~mL})$ and CDI $(11 \mathrm{mg}, 1.5$ eq. $)$ was added. The reaction mixture was stirred for $30 \mathrm{~min}$ and the complex $\left.\mathrm{FeBd}_{2}\left(\mathrm{OHC}_{2} \mathrm{H}_{4} \mathrm{~S}\right)_{2} \mathrm{Gm}\right)(\mathrm{BF})_{2}(10 \mathrm{mg}, 0.25$ eq. $)$ was added. The reaction mixture was stirred overnight at room temperature and then water $(1 \mathrm{~mL})$ was added to this mixture. The obtained solution/suspention was stirred for $30 \mathrm{~min}$ and then rotary evaporated to dryness. The obtained solid residue was chromatographically separated on silica gel (eluent: acetonitrile - methanol 3:2 $(\mathrm{v} / \mathrm{v})$ mixture) and the clathrochelate product with $\mathrm{R}_{\mathrm{f}}=0.55$ was isolated in a trace amount as described above.

$\mathrm{FeBd}_{2}\left(\left(\mathrm{HOOCC}_{6} \mathrm{H}_{4} \mathrm{~S}\right) \mathrm{Gm}\left(\mathrm{SC}_{6} \mathrm{H}_{4} \mathrm{COCoum}\right)\right)(\mathrm{BF})_{2}$ Complex $\mathrm{FeBd}_{2}\left(\left(\mathrm{HOOCC}_{6} \mathrm{H}_{4} \mathrm{~S}\right)\left(\mathrm{HC}^{\circ} \mathrm{CCH}_{2} \mathrm{NHCOC}_{6} \mathrm{H}_{4} \mathrm{~S}\right) \mathrm{Gm}\right)$ $(\mathrm{BF})_{2}(10 \mathrm{mg}, 9.8 \mu \mathrm{mol}), 3$-azido-7-(di)chromen-2-one $(2.53 \mathrm{mg}$, $9.8 \mu \mathrm{mol}), \mathrm{CuI}(0.18 \mathrm{mg}, 0.98 \mu \mathrm{mol})$ and TBTA $(0.52 \mathrm{mg}, 0.98 \mu \mathrm{mol})$ were dissolved/suspended in acetonitrile $(0.5 \mathrm{~mL})$ and di-isopropylamine $(8.54 \mu \mathrm{L}$, ) was added. The reaction mixture was stirred at $60^{\circ} \mathrm{C}$ for $4 \mathrm{~h}$, then poured into $1 \mathrm{M}$ aqueous hydrochloric acid $(1 \mathrm{~mL})$ and extracted with dichloromethane $(3 \mathrm{ml}$, in three portions). The combined extract was washed with brine and dried with $\mathrm{Na}_{2} \mathrm{SO}_{4}$. Then it was chromatographically separated by column chromatography on silica gel (eluent: dichloromethane - isopropanol 19:1 (v/v) mixture). Evaporation of the major elute with $\mathrm{R}_{\mathrm{f}}=0.7$ gave the target clathrochelate product in a form of the orange-red fine-crystalline powder. Yield: $7.73 \mathrm{mg}(63 \%)$. Calcd. for $\mathrm{C}_{60} \mathrm{H}_{47} \mathrm{~B}_{2} \mathrm{~F}_{2} \mathrm{FeN}_{11} \mathrm{O}_{11} \mathrm{~S}_{2}$ : C, 56.40; H, 3.71; N, 12.06; S, 5.02. Found (\%): C, 56.22; H, 3.92; N, 11.93; S, 4.83. ESI-TOF MS (positive range) $m / z$ : Calcd. for $\mathrm{C}_{60} \mathrm{H}_{47} \mathrm{~B}_{2} \mathrm{~F}_{2} \mathrm{FeN}_{11} \mathrm{O}_{11} \mathrm{~S}_{2}$ : 1277.54 . Found: $1278.2492 .{ }^{~} \mathrm{H}$ NMR (400 MHz, acetone- $\left.d_{6}\right) \delta_{\mathrm{H}} \mathrm{ppm}: 1.10$ $\left(\mathrm{t}, J 1_{H-} 1_{H}=7.0 \mathrm{~Hz}, 6 \mathrm{H}\right), 3.42\left(\mathrm{q}, J 1_{H-} 1_{H}=7.0 \mathrm{~Hz}, 4 \mathrm{H}\right), 5.48(\mathrm{~s}, 1 \mathrm{H})$, $4.61 \mathrm{~s}, 2 \mathrm{H}), 6.48\left(\mathrm{~d}, J l_{H-} l_{H}=2.3 \mathrm{~Hz}, 1 \mathrm{H}\right), 6.71\left(\mathrm{dd}, J l_{H-} l_{H}=8.9\right.$, $2.4 \mathrm{~Hz}, 1 \mathrm{H}), 7.34-7.10(\mathrm{~m}, 24 \mathrm{H}), 7.48\left(\mathrm{~d}, J 1_{H_{-}} 1_{H}=8.9 \mathrm{~Hz}, 1 \mathrm{H}\right)$, $7.76\left(\mathrm{~d}, J 1_{H-} 1_{H}=7.6 \mathrm{~Hz}, 2 \mathrm{H}\right), 7.82(\mathrm{~s}, 1 \mathrm{H}), 8.23(\mathrm{~s}, 1 \mathrm{H}), 8.36(\mathrm{~s}$,
$1 \mathrm{H}) .{ }^{13} \mathrm{C}\{1 \mathrm{H}\}$ NMR (101 MHz, acetone- $\left.d_{6}\right) \delta_{\mathrm{C}}$ ppm: 11.82, 21.97, 28.36, 28.56, 28.75, 28.94, 29.13, 29.33, 29.52, 44.53, 96.66, 106.95, $110.04,127.99,128.02,128.37,129.30,129.42,130.29,130.62$, 135.27, 151.81, 157.67, 205.28.

\section{Results and Discussion}

On the first stage, we tested an ability of the esterification reaction(s) by Scheme 1 to be used for modification of the iron(II) clathrochelates with terminal reactive hydroxyl group(s), thus giving cage complexes with distal fluorophoric group(s) in their ribbed substituent(s). For this purpose, we obtained the earlier described ${ }^{[2]}$ reactive mono(1)- and di(2)-topic macrobicyclic precursors - the derivatives of mecraptoethanol. It should be noted that, trying to perform a nucleophilic substitution of their iron(II)-encapsulating dichloroclatrochelate precursor $\mathrm{FeBd}_{2}\left(\mathrm{Cl}_{2} \mathrm{Gm}\right)(\mathrm{BF})_{2}$ with the corresponding aliphatic thiolate monoanion as a $S$-nucleophile, generated in situ in the presence of triethylamine, we unexpectedly observed an inversion of the reactivity of its two reactive chlorine atoms in a vic-position of the same chelate ribbed fragment. Indeed, in the case of polyhalogenide organic compounds, after a nucleophilic substitution of their first halogen atom, the reactivity of other atoms of this type usually decreases. Contrary, in the case of this iron(II) dichloroclathrochelate as a reactive substrate, the main reaction product of nucleophilic substitution of its first ribbed chlorine atom under the mild reaction conditions (in dichloromethane as a solvent at $-5{ }^{\circ} \mathrm{C}$ ) was the corresponding disubstituted clathrochelate 2 (Scheme 1), while the target monofunctionalized complex 1 was obtained in only $10 \%$ yield. This suggests that such substitution of the first chlorine atom of its dichloroglyoximate ligand synthon, giving the corresponding monochloromonosulfide ribbed fragment, caused an increase in the reactivity of its second vic-chlorine atom

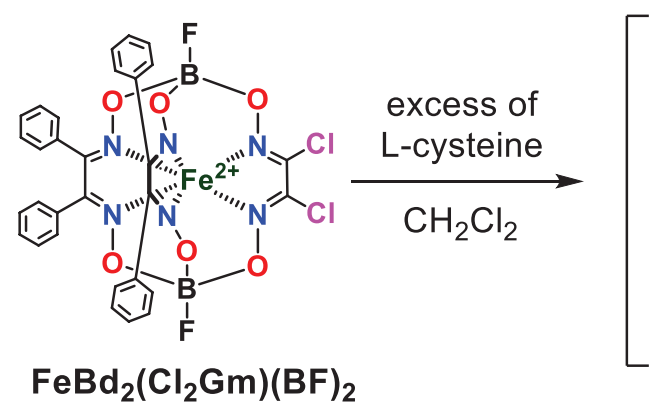

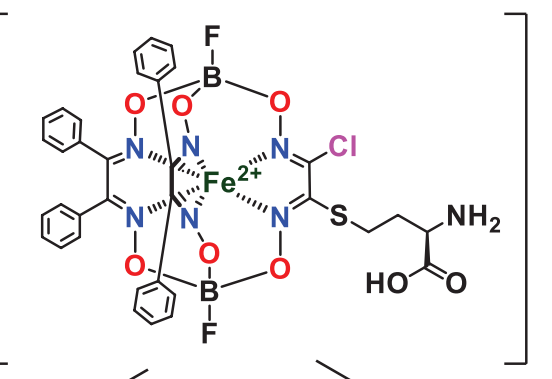

$\mathrm{FeBd}_{2}\left(\mathrm{Cl}_{2} \mathrm{Gm}\right)(\mathrm{BF})_{2}$

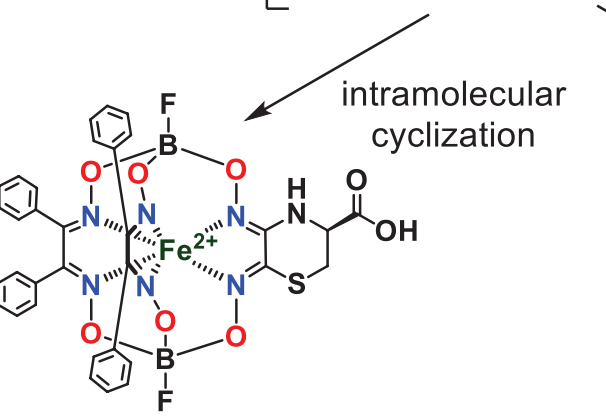<smiles>CC(C)(C)C</smiles>

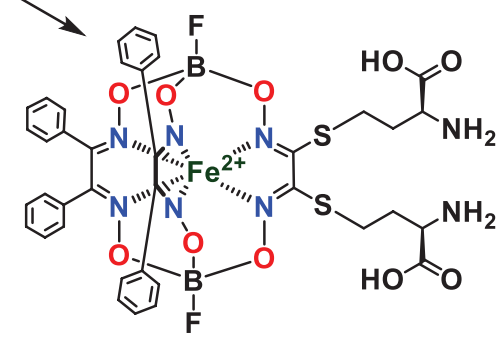

$\mathrm{FeBd}_{2}\left(\mathrm{HNCH}(\mathrm{COOH}) \mathrm{CH}_{2} \mathrm{SGm}\right)(\mathrm{BF})_{2}$

Scheme 1. Increase in a reactivity of the second vic-halogen atom in the same chelating fragment of a cage tris- $\alpha$-dioximate framework: the formation of a $N, S$-heterocyclic ribbed substituent. 
in the same chelating $\alpha$-dioximate moiety. The same effect was also observed in the case of our attempts to modify the above dichloroclathrochelate precursor with $L$-cysteine. The latter chemical transformation was also performed under the mild reaction conditions at $10{ }^{\circ} \mathrm{C}$ using dichloromethane as a solvent. Its main isolated clathrochelate product was found to contain a six-membered $S, N$-heterocyclic ribbed substituent at its quasiaromatic tris-dioximate cage framework (Scheme 1). The analogous cyclization reaction has been earlier observed ${ }^{[18]}$ in the case of nucleophilic substitution of $\mathrm{FeBd}_{2}\left(\mathrm{Cl}_{2} \mathrm{Gm}\right)(\mathrm{BF})_{2}$ with 3-dimethylaminopropylamine. It should be noted that the above substitution of the second chlorine atom in the same ribbed chelating fragment of a macrobicyclic tris- $\alpha$-dioximate framework is characteristic behavior of the reactions of metal(II) polyhalogenoclathrochelates with such sterically unhindered primary aliphatic amines as $N$-nucleophiles. ${ }^{[19]}$

So, trying to obtain the target monofunctionalized monochloroclathrochelate product - the derivative of mercaptoethanol - in a higher yield, we modified the synthetic procedure of such nucleophilic substitution. For this purpose, the solutions of triethylamine and this $S$-nucleophilic agent in dichloromethane were simultaneously added dropwise at $-45^{\circ} \mathrm{C}$ under argon to that of two-fold excess of the dichloroclathrochelate precursor $\mathrm{FeBd}_{2}\left(\mathrm{Cl}_{2} \mathrm{Gm}\right)(\mathrm{BF})_{2}$ in its dichloromethane solution, keeping a control of the rate of such simultaneous mixing of the equiproportional volumes of the above solutions and of time of their addition as well (Scheme 2). Under these reaction conditions, the complete recovery of the above unreacted dichloroclathrochelate precursor can be performed and the corresponding monoand difunctionalized clathrochelate products were isolated in their molar ratio 3:1. Then, the mono- and di-cyan1-terminated iron(II) clathrochelates were obtained by Scheme 3 in the very low yields (less than $5 \%$ ) by condensation of thus obtained hydroxyl-terminated cage complexes with cyan1 in the presence of CDI as a coupling agent.

The isolated clathrochelate products were studied using the ESI-TOF mass spectrometry experiments and they were found to be unstable under their experiment conditions. The di-cyan1-containing iron(II) clathrochelate was characterized by the fragmentation MS-experiments (Figure 1). Its fragmentation was observed in the ESI-TOF mass spectrum of a minor fraction with a threshold of 58 atomic units. The molecular peaks of these macrobicyclic complexes in this spectrum are absent (in particular, the calculated $\mathrm{m} / \mathrm{z}$ value for such difunctionalized clathrochelate $\mathrm{C}_{92} \mathrm{H}_{94} \mathrm{~B}_{2} \mathrm{~F}_{2} \mathrm{FeN}_{10} \mathrm{O}_{16} \mathrm{~S}_{4}$ is equal to 1839.52), but an extrapolation of the corresponding experimental plot gave to the target mass peak of 5. Unfortunately, the corresponding mass peak of its monofunctionalized analog 4 was not observed, but a study of the above fragmentation ESI-TOF mass spectra of this minor fraction allowed us to find the molecular peaks of one of its fragments (Figure 2).

So, under the above esterification reaction conditions, the target modification of the iron(II)-encapsulating clathrochelate molecular platforms, giving the cage complexes with fluorescent labelling group(s), allowed to obtain them in a very low yield, if any (trace amounts) and this synthetic pathway seems to be ineffective.

Therefore, on the next stage, we choose to change a linker fragment between a quasiaromatic tris- $\alpha$-dioximate cage framework and an fluorescent terminal group, trying to increase an yield of the corresponding labelled clathrochelate complex. For this purpose, we used the earlier described ${ }^{[20]}$ propargylamine iron(II) clathrochelate complex with a terminal reactive $\mathrm{C} \equiv \mathrm{C}$ bond as the reactive macrobicyclic precursor for its further functionalization using the well-known copper-promoted "click" reactions. ${ }^{[21-28]}$ Indeed, the coumarin-terminated iron(II) cage complex was obtained by 1,3-dipolar cycload-

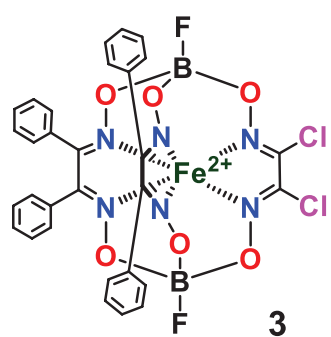

3

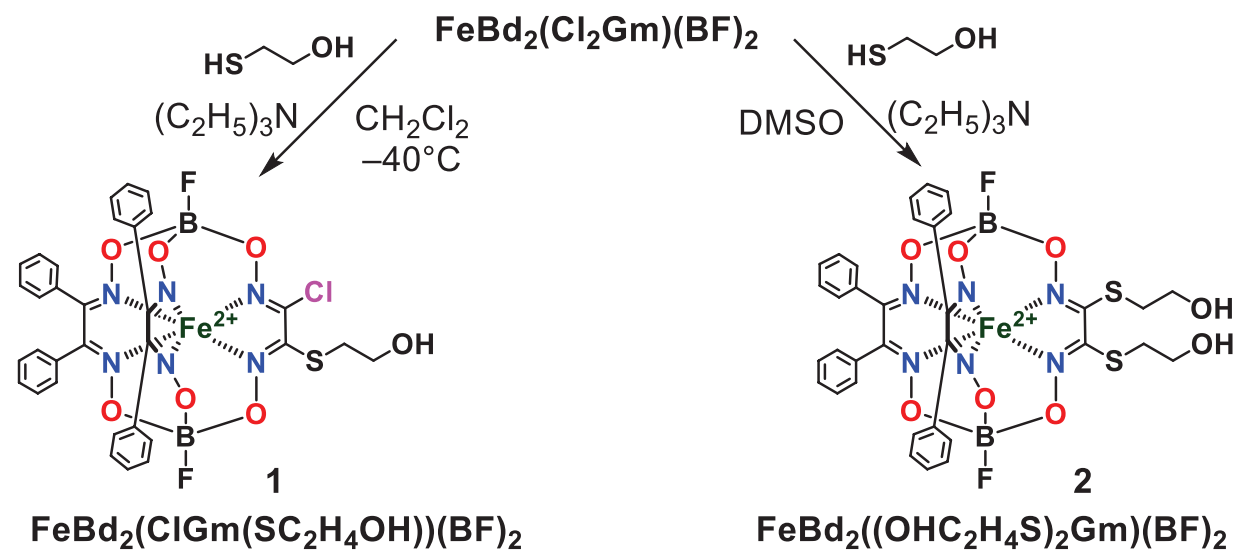

Scheme 2. Preparation of the iron(II) clathrochelates with terminal hydroxyl group(s) - the derivatives of mercaptoethanol. 
Fluorescently Labelled Iron(II) Clathrochelates

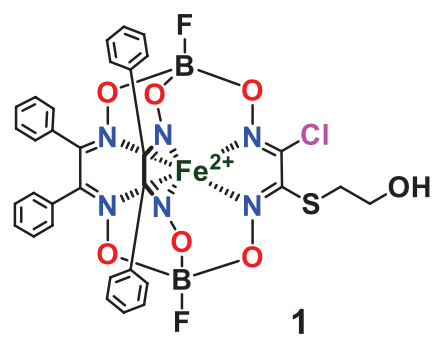

$\mathrm{FeBd}_{2}\left(\mathrm{CIGm}\left(\mathrm{SC}_{2} \mathrm{H}_{4} \mathrm{OH}\right)\right)(\mathrm{BF})_{2}$

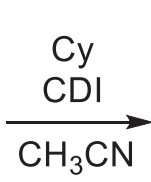

Cy

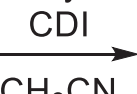

$\mathrm{CH}_{3} \mathrm{CN}$

cyan1

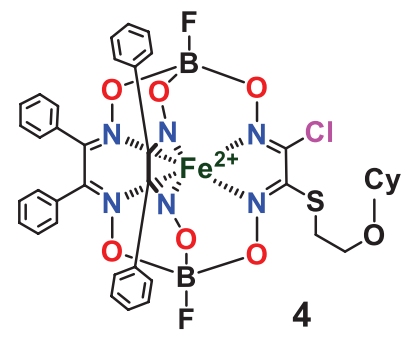

$\mathrm{FeBd}_{2}\left(\mathrm{CIGm}\left(\mathrm{SC}_{2} \mathrm{H}_{4} \mathrm{OCyan1}\right)\right)(\mathrm{BF})_{2}$

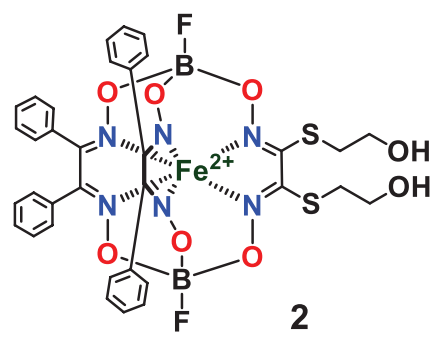

$\mathrm{FeBd}_{2}\left(\left(\mathrm{OHC}{ }_{2} \mathrm{H}_{4} \mathrm{~S}\right)_{2} \mathrm{Gm}\right)(\mathrm{BF})_{2}$

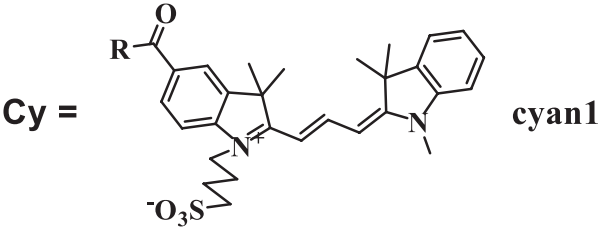

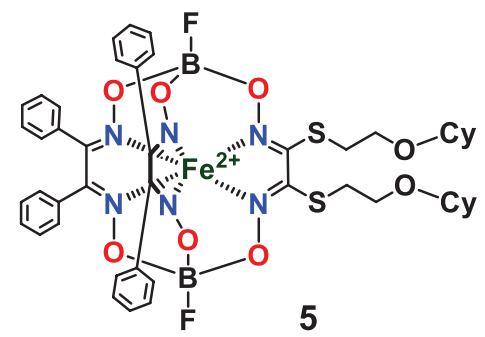

$\mathrm{FeBd}_{2}\left(\left(\mathrm{Cyan} 10 \mathrm{C}_{2} \mathrm{H}_{4} \mathrm{~S}\right)_{2} \mathrm{Gm}\right)(\mathrm{BF})_{2}$<smiles>O=C(n1ccnc1)n1ccnc1</smiles>

Scheme 3. Preparation of the mono- and di-cyan1-functionalized iron(II) clathrochelates.

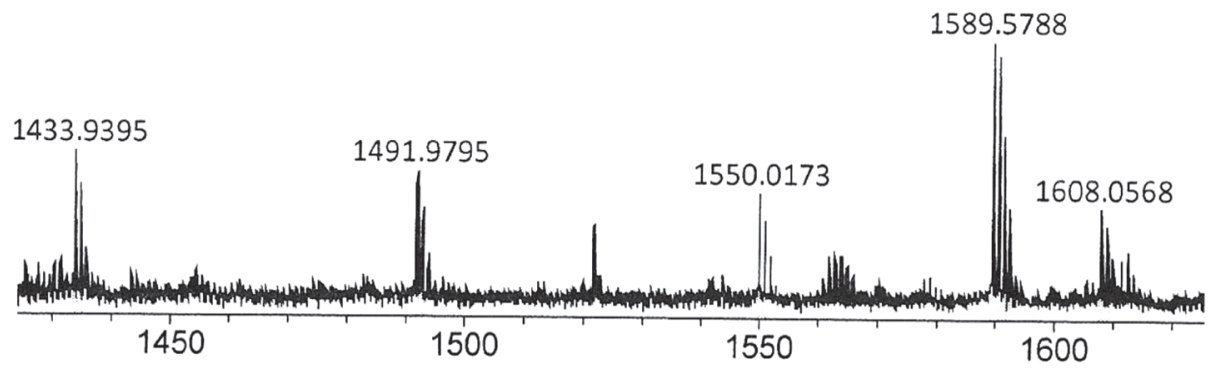

Figure 1. Part of the fragmentation ESI-TOF mass spectrum of 5.

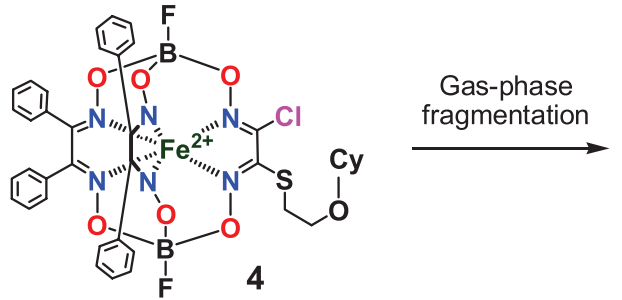

$\mathrm{FeBd}_{2}\left(\mathrm{ClGm}\left(\mathrm{SC}_{2} \mathrm{H}_{4} \mathrm{OCyan1}\right)\right)(\mathrm{BF})_{2}$

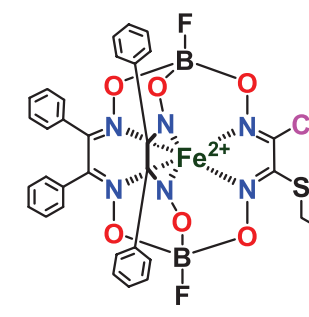

Chemical Formula: $\mathrm{C}_{47} \mathrm{H}_{41} \mathrm{~B}_{2} \mathrm{ClF}_{2} \mathrm{FeN}_{7} \mathrm{O}_{11} \mathrm{~S}_{2} \cdot 2$ Exact Mass: 1094,15
1095.4106 Exact Mass: 198,13

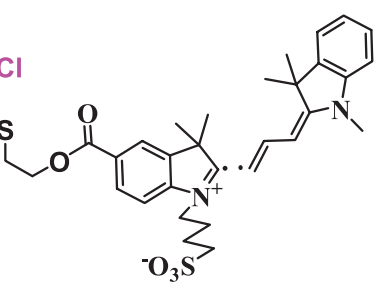

$$
2^{-2+}
$$

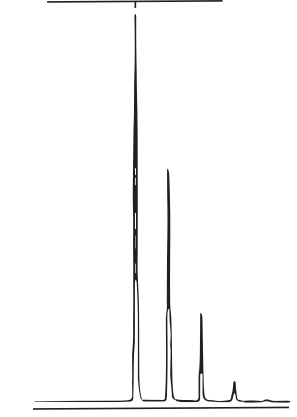

Figure 2. Peaks of a given fragmental molecular ion in the ESI-TOF mass spectrum of 4. 


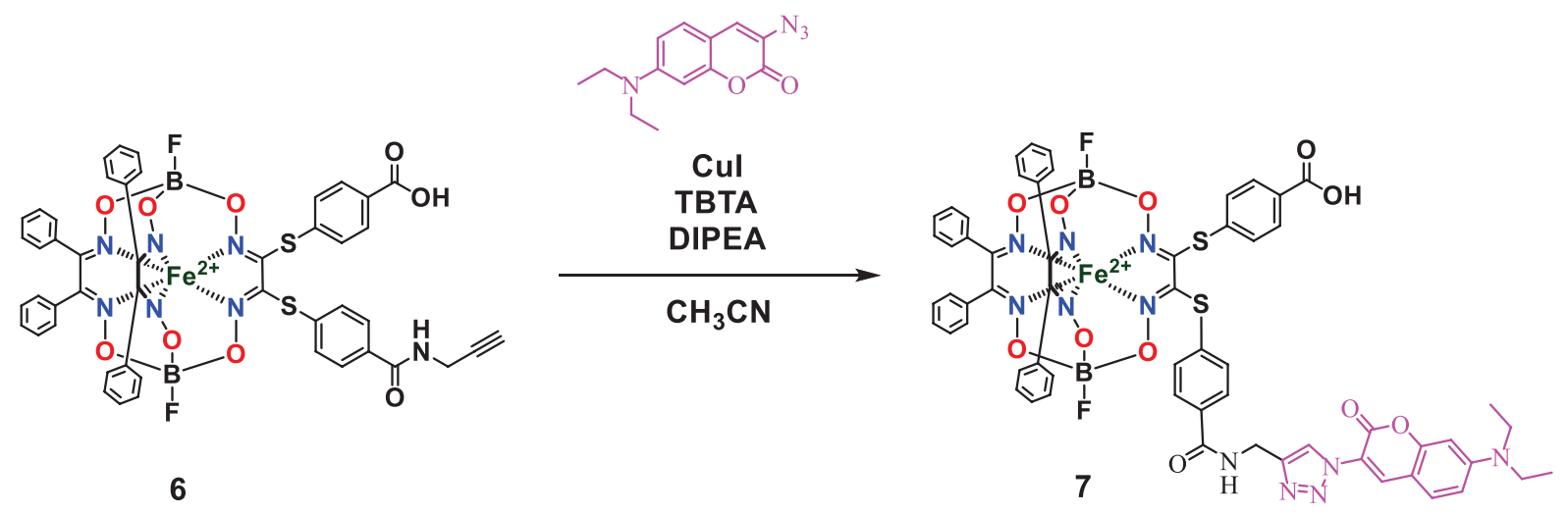

$\mathrm{FeBd}_{2}\left(\left(\mathrm{HOOCC}_{6} \mathrm{H}_{4} \mathrm{~S}\right) \mathrm{Gm}\left(\mathrm{HC} \equiv \mathrm{CCH}_{2} \mathrm{NHCOC}_{6} \mathrm{H}_{4} \mathrm{~S}\right)\right)(\mathrm{BF})_{2}$

$\mathrm{FeBd}_{2}\left(\left(\mathrm{HOOCC}_{6} \mathrm{H}_{4} \mathrm{~S}\right) \mathrm{Gm}\left(\mathrm{SC}_{6} \mathrm{H}_{4} \mathrm{COCoum}\right)\right)(\mathrm{BF})_{2}$

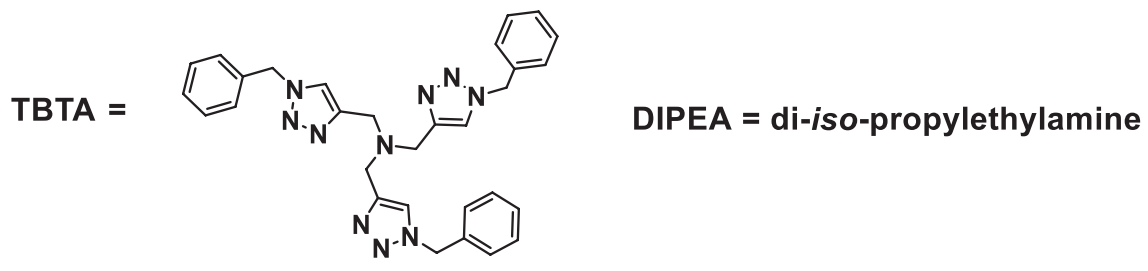

Scheme 5. Functionalization of the iron(II)-encapsulating clathrochelate molecule with a terminal coumarin group.

dition using the corresponding one-pot copper-promoted "click"-reaction shown in Scheme 5.

The target macrobicyclic product was obtained in a high yield. Unfortunately, we found that its quasiaromatic cage framework substantially quenches an intrinsic fluorescence of the terminal coumarin group that we plan to use for molecular imaging of the above iron(II) clathrochelate. So, the latter complex cannot be used for this purpose and a further search of the appropriate fluorophoric and linker groups should be performed in order to obtain the fluorescent iron(II) clathrochelates, which will be suitable for the fluorescent cellular experiments as both the molecular optical probes and the fluorescent tags.

\section{Conclusions}

Thus, we compared the esterification and 1,3-dipolar cycloaddition reactions as most common synthetic approaches for functionalization of the clathrochelate molecular platforms, allowing to obtain the fluorescently labelled iron(II) clathrochelates, and, therefore, to study their localization and accumulation in cancer cells. The use of esterification reactions allowed to obtain these target macrobicyclic compounds in very low yields, if any. So, we changed a linker fragment between a quasiaromatic tris- $\alpha$-dioximate cage framework and a fluorescent terminal group, thus trying to increase an yield of the corresponding labelled cage complex. A known propargylamine iron(II) clathrochelate with terminal $\mathrm{C} \equiv \mathrm{C}$ bond was used as a reactive macrobicyclic precursor for its further functionalization by the copper-promoted 1,3-dipolar cycloaddition "click" reaction. As a result, the coumarin-terminated iron(II) cage complex was obtained in the high yield using the corresponding one-pot synthetic procedure. Unfortunately, its quasiaromatic cage framework was found to substantially quench an intrinsic fluorescence of the terminal coumarin group and, therefore, it cannot be used for molecular imaging. So, a further search of the appropriate fluorophoric and linker groups should be performed in order to obtain the fluorescent iron(II) clathrochelates which are suitable for the fluorescent cellular experiments as the molecular optical probes and the fluorescent tags.

Acknowledgements. The project leading to these results has received funding from the European Union's Horizon 2020 research and innovation programme under the Marie Skłodowska-Curie grant agreement no. 778245. Y.Z.V. also thanks the financial support of the Russian Foundation for Basic Research (grant 18-29-23007) for supporting of the synthesis of clathrochelate precursors. The analytical part was performed in a framework of the IGIC RAS state assignment in the field of basic scientific research.

\section{References}

1. Voloshin Y.Z., Kostromina N.A., Krämer R. Clathrochelates: Synthesis, Structure and Properties. Amsterdam: Elsevier, 2002.

2. Voloshin Y.Z., Belaya I.G., Krämer R. Cage Metal Complexes: Clathrochelates Revisited. Heidelberg: Springer, 2017 [Волошин Я.З., Белая И.Г., Кремер Р. Клеточные комплексы металлов: клатрохелаты возвращаются. Граница, Москва, 2019].

3. Novikov V.V., Varzatskii O.A., Negrutska V.V., Bubnov Y.N., Palchykovska L.G., Dubey I.Y., Voloshin Y.Z. J. Inorg. Biochem. 2013, 124, 42.

4. Varzatskii O.A., Novikov V.V., Shulga S.V., Belov A.S., Vologzhanina A.V., Negrutska V.V., Dubey I.Y., Bubnov Y.N., Voloshin Y.Z. Chem. Commun. 2014, 50, 3166. 
5. Varzatskii O.A., Shul'ga S.V., Belov A.S., Novikov V.V., Dolganov A.V., Vologzhanina A.V., Voloshin Y.Z. Dalton Trans. 2014, 43, 17934.

6. Varzatskii O.A., Vologzhanina A.V., Novikov V.V., Vakarov S.V., Oblap R.V., Voloshin Y.Z. Inorg. Chim. Acta 2018, 482, 90.

7. Kovalska V.B., Losytskyy M.Yu., Varzatskii O.A., Cherepanov V.V., Voloshin Y.Z., Mokhir A.A., Yarmoluk S.M., Volkov S.V. Bioorg. Med. Chem. 2014, 22, 1883.

8. Kovalska V., Chernii S., Cherepanov V., Losytskyy M., Chernii V., Varzatskii O., Naumovets A., Yarmoluk S. J. Molecular Recognition 2017, 30, e2622

9. Losytskyy M.Y., Kovalska V.B., Varzatskii O.A., Sergeev A.M., Yarmoluk S.M., Voloshin Y.Z. J. Fluoresc. 2013, 23, 889.

10. Kovalska V.B., Vakarov S.V., Kuperman M.V., Losytskyy M.Yu., Gumienna-Kontecka E., Voloshin Y.Z., Varzatskii O.A. Dalton Trans. 2018, 47, 1036.

11. Kovalska V., Kuperman M., Losytskyy M., Vakarov S., Potocki S., Yarmoluk S., Voloshin Y., Varzatskii O., Gumienna-Kontecka E. Metallomics 2019, 11, 338.

12. Kovalska V., Vakarov S., Losytskyy M., Kuperman M., Chornenka N., Toporivska Y., Gumienna-Kontecka E., Voloshin Y., Varzatskii O., Mokhir A. RSC Adv. 2019, 9, 24218.

13. Kovalska V., Vakarov S., Chornenka N., Gumienna-Kontecka E., Voloshin Y. Russ. J. Inorg. Chem. 2020, 65, 1513.

14. Blechinger J., Varzatskii O.A., Kovalska V., Zelinskii G.E., Voloshin Y.Z., Kinski E., Mokhir A. Bioorg. Med. Chem. Lett. 2016, 26, 626.

15. Achimovich A.M., Ai H., Gahlmann A. Curr. Opin. Struct. Biol. 2019, 58, 224.

16. Ponzio G., Baldrocco F. Gazz. Chim. Ital. 1930, 60, 415.
17. Voloshin Y.Z., Zavodnik V.E., Varzatskii O.A., Belsky V.K., Palchik A.V., Strizhakova N.G., Vorontsov I.I., Antipin M.Yu. Dalton Trans. 2002, 1193.

18. Zelinskii G.E., Belov A.S., Vologzhanina A.V., Novikov V.V., Varzatskii O.A., Voloshin Y.Z. Inorg. Chem. Commun. 2016, 67,80 .

19. Voloshin Y.Z., Zavodnik V.E., Varzatskii O.A., Belsky V.K., Vorontsov I.I., Antipin M.Y. Inorg. Chim. Acta 2001, 321, 116.

20. Selin R.A., Chornenka N.V., Chernii V.Ya., Mokhir A., Vologzhanina A.V., Belov A.S., Pomadchik A.L., Voloshin Y.Z. Inorg.Chim.Acta 2019, 496, 119047.

21. a) Kolb H.C., Finn M.G., Sharpless K.B. Angew. Chem. 2001, 113, 2056; b) Kolb H.C., Finn M.G., Sharpless K.B. Angew. Chem. Int. Ed. 2001, 40, 2004.

22. a) Rostovtsev V.V., Green L.G., Fokin V.V., Sharpless K.B. Angew. Chem. 2002, 114, 2708; b) Rostovtsev V.V., Green L.G., Fokin V.V., Sharpless K.B. Angew. Chem. Int. Ed. 2002, 41, 2596.

23. Agalave S.G., Maujan S.R., Pore V.S. Chem. Asian J. 2011, 6 , 2696.

24. Ol'shevskaya V.A., Makarenkov A.V., Kononova E.G., Petrovskii P.V., Verbitskiy E.V., Rusinov G.L., Charushin V.N., Hey-Hawkins E., Kalinin V.N. Polyhedron 2012, 42, 302.

25. Rokitskaya T.I., Khailova L.S., Makarenkov A.V., Shunaev A.V., Tatarskiy V.V., Shtil A.A., Ol'shevskaya V.A., Antonenko Y.N. BBA-Biomembranes 2019, 1861, 573.

26. Dheer D., Singh V., Shankar R. Bioorg. Chem. 2017, 71, 30.

27. Zelinskii G.E., Belov A.S., Vologzhanina A.V., Limarev I.P., Pavlov A.A., Olshevskaya V.A., Makarenkov A.V., Dorovatovskii P.V., Lebed E.G., Voloshin Y.Z. Chemistry Select 2019, 4, 11572.

28. Selin R., Chernii V., Mokhir A. Ukr. Chem. J. 2020, 86, 3. 